\title{
$\mathrm{ZrO}_{2}$ 表面強化ムライト複合体の作製とその機械特性
}

\author{
浅海順治・吉田秀人 · 宮田昇・上赤日出人 ·山岸千丈 \\ (日本セメント(株) 中央研究所, 135 東京都江東区清澄 1-2-23)
}

\section{Surface Modification of Mullite by Partial Infiltration of Zirconia}

Junji ASAUMI, Hideto YOSHIDA, Noboru MIYATA, Hideto KAMIAKA and Chitake YAMAGISHI

(Nihon Cement Co., Ltd., 1-2-23, Kiyosumi, Kohtoh-ku, Tokyo

135)

\begin{abstract}
A fabrication technique for surface incorporation of $\mathrm{ZrO}_{2}$ was developed. Prefired mullite bodies with open porosities of 20-40\% were infiltrated with a $\mathrm{ZrOCl}_{2}$ solution prior to firing. Mechanical properties of the surface modified mullite were improved. The flexural strength of the composite increased by $35-40 \%$ of that of mullite at room temperature, and had the same value at $1300^{\circ} \mathrm{C}$ as that of mullite. The fracture toughness of the surface layer of the composite was double of that of mullite.

[Received June 20, 1989; Accepted October 3, 1989]
\end{abstract}

Key-words : Infiltration, Surface modification, Mullite, Zirconia

\section{1. 緒 言}

ムライト中の不純物を極力少なくしかつ厳密なムライ 卜組成 $\left(3 \mathrm{Al}_{2} \mathrm{O}_{3} \cdot 2 \mathrm{SiO}_{2}\right)$ をもつ粉末合成技術 ${ }^{1}$ が確立さ れ, しかも焼結体組織の制御技術の進歩 ${ }^{1}$ が計られたこ とにより，近年ムライトセラミックスは，他のセラミッ クスにみられない高温強度の高さ ${ }^{1,2)}$ と耐クリープ性 ${ }^{3)} の$ よさなどの特性を示すことが明らかになった。ムライト は元来酸化物であり, 非酸化物系セラミックスにみられ る大気中での酸化劣化は問題にならない。したがって, 高純度ムライト焼結体は, 高温でも強度低下を示さない ことにより高温用構造材料として注目を集めてきてい る.しかしながら，この焼結体は，破壊勒性が低(4) よ いう欠点を有している。

ムライトセラミックスの欠点を改善する方法として, ムライト中に他の成分を均一に複合化した種々の系が検 討されている．例えば，ムライトに SiC ウィスカーを 複合化 ${ }^{5)}$ すると高温強度, 勒性ともムライトより優れた 特性を示す. しかし, $\mathrm{SiC}$ が非酸化物であるため, 高 温酸化雾囲気での酸化劣化による寿命が問題となる. ま た，ムライトに $\mathrm{ZrO}_{2}$ を均一に複合すると, 常温強度と 靫性の向上は認められる ${ }^{6)}$ が $\mathrm{ZrO}_{2}$ を添加したため, ム ライト本来の特長である高温強度や耐クリープが低下し てしまゔリ.したがって，ムライト本来の優れた耐酸化 性, 高温高強度を維持して勒性を改善できた複合系はい まだ報告されていないのが現状である.
ところで, セラミックスの強度は，セラミックス中に 存在する欠陥によって支配され, 久陥の大きさを少なく することにより強度が改善できるといわれている8 たがって, ムライトセラミックス焼結体を, 高純度のム ライト粉末を用いて, 焼結体中に異常粒成長やポアので きにくい焼結技術で調製すれば，七ラミックス中の欠陥 を極力低下させることができる．有限要素法による構造 解析によれば, 一般に, 構造用部材にかかる最大応力は, 部材の表面付近に集中することが多い. また，七ラミッ クス部材は, 加工中等で表面に微細な傷を受けることも 多い. したがって, 表面につく微細な傷の発生を防止で きれば表面から発生するセラミックス部材の破壊が低減 できるため, その寿命を延ばすことが可能である。こう した観点に立つと, 従来, 主に行われてきたムライトに 他の成分を均一複合させることによってその特性をかえ る試みのほかに，ムライトの表面の特性のみを部分的に かえることにより，ムライトの高温特性の利点を損わず かつ機械特性の改善の可能性も考えられると思われる.

セラミックスの表面を部分強化する考え方として, 古 くは $\mathrm{Cr}_{2} \mathrm{O}_{3}{ }^{9}$ で表面強化したアルミナセラミックスなど があり, 最近ではアルミナをイットリア部分安定化 $\mathrm{ZrO}_{2}$ に含浸した複合体あるいは, アルミナ表面に $\mathrm{SiO}_{2}$ を含浸させムライト化することにより複合したアルミナ セラミックス ${ }^{10), 11 /}$ 功研究されている。これらの系では, 複合表面に圧縮応力の発生を期待している. 
ところで，セラミックスの表面を部分強化する考え方 にたって，ムライトセラミックスの表面部分のみを $\mathrm{ZrO}_{2}$ で複合化すると，ムライトの表面部に $\mathrm{ZrO}_{2}$ によ る応力誘起変態に伴う圧縮応力の発生が期待でき, かつ 内部はムライトの性能が保持できるのでムライト焼結体 の改善が可能と思われるが，本系については，いまだ報 告されていない.

本研究の目的は, ムライトセラミックスの欠点を改善 する方法として，従来行われてきたムライト中に $\mathrm{ZrO}_{2}$ 成分を均一に複合化する方法によるのではなく，ムライ トの表面層を $\mathrm{ZrO}_{2}$ を用いて改善することにより，ムラ イト本来の高温強度を低下させることなく焼結体の鞀性 を向上させることにある。

今回用いた表面複合方法は, 開気孔率 20〜 40\%をも つムライト成形仮焼体（以後 1 次焼結体と呼ぶ）に才キ シ塩化ジルコニウム溶液を表面から含浸させ, 熱分解す ることによって $\mathrm{ZrO}_{2}$ を表面部のみに析出させてから 2 次焼成して複合体を得る方法である。本法は，(1)部材形 状の制約をうけないで表面強化を簡単に行える調製法で あり，(2)調製工程が簡単であり，(3)表面層とバルク層を 一体構造で製造でき，(4)表面層の剝離や複合体の反りが 起りにくい構造である，等の利点をもつものである.

以下に, $\mathrm{ZrO}_{2}$ 表面強化ムライト系複合体の作製方法 とその機械特性について報告する.

\section{2. 実験方法}

\section{1 試料調製}

原料として用いたムライト粉末（日本セメント製， AM-72S） は噴霧熱分解法で合成した高純度微粉末であ る (平均粒径 $0.2 \mu \mathrm{m}$, 純度 $99.9 \%, \mathrm{Fe}_{2} \mathrm{O}_{3} 100 \mathrm{ppm}$, $\mathrm{Na}_{2} \mathrm{O} 100 \mathrm{ppm}, \mathrm{K}_{2} \mathrm{O} 60 \mathrm{ppm}, \mathrm{TiO}_{2} 60 \mathrm{ppm}$ ). 試料の調 製方法を以下に述べる。 まずムライト粉末を, メ夕ノー ル中でボールミル粉砕した。 得られたスラリーを，ロー タリーエバポレーターを用いて乾燥し, 更に $120^{\circ} \mathrm{C}$ の 乾燥機中で 16 時間乾燥させた後, 100 メッシュでうら ごしして整粒粉末とした.この粉末を, 金型 $(25 \times 50 \mathrm{~mm})$ にてプレス成形 $(31 \mathrm{MPa})$ 後, CIP (196 MPa) 処理し, $47 \%$ の相対密度を持つ成形体を得た。この成形体を, $10^{\circ} \mathrm{C} / \mathrm{min}$ で昇温し，1 次焼成温度 $\left(1550^{\circ} \sim 1610^{\circ} \mathrm{C}\right)$ で 10 分保持した後，自然冷却させることにより，1 次焼結 体を調製した．2次焼結条件の検討には，20 mm $\phi$ (金 型サイズ）の試料を用いた。

\section{2 含浸法}

今回用いた含浸溶液は, オキシ塩化ジルコニウム（第 一稀元素化学工業製 ZC-2）で， $\mathrm{ZrO}_{2}$ 換算成分 33.4 $\mathrm{wt} \%$, 粘度 $23 \mathrm{cP}$ である. 含浸には, 1 次焼結体を常温 大気中で，オキシ塩化ジルコニウム溶液中に所定時間浸 漬させる方法を採用した. 含浸後の 1 次焼結体は, 室温
から $5^{\circ} \mathrm{C} / \mathrm{min}$ の昇温速度で所定温度まで昇温しオキシ 塩化ジルコニウムを熱分解し， $\mathrm{ZrO}_{2}$ を 1 次焼結体表面 部に析出させた。多段含浸の場合には，この含浸工程を 繰返した． 2 次焼成体は，含浸熱分解後の試料を室温か ら $10^{\circ} \mathrm{C} / \mathrm{min}$ で所定温度まで昇温し，4 時間保持した後 自然冷却して得た。比較のために用いたムライト単味の 焼結体は, CIP 後 1 次焼成せず, 直接 2 次焼成するこ とにより得た。

\section{3 測定法}

焼結体のかさ密度は，アルキメデス法により求めた。 焼結体の相対密度と気孔率 (閉気孔) は, ムライトの理 論密度 $3.15 \mathrm{~g} / \mathrm{cm}^{3}$ を用いて求めた. ムライト表面より $\mathrm{ZrO}_{2}$ がムライト内部へ浸透した距離（含浸距離）は, オキシ塩化ジルコニウムを含浸した試料を二つに切断 し, 断面に $\mathrm{pH}$ 指示薬を滴下して変色までの距離を, 実 体顕微鏡で測定して求めた. 2 次焼結体の微構造は, 表 面研磨後, サーマルエッチングしたものを走査型電子顕 微鏡（SEM：日立製 S-405）を用いて観察した。オキ シ塩化ジルコニウム溶液の熱分析は, 示差熱天秤 (理学 電機製 $\mathrm{CN} 8002 \mathrm{H} 2)$ を用いて, 昇温速度 $10^{\circ} \mathrm{C} / \mathrm{min}$ で 測定した。焼結体の構成相は, X 線回折装置（理学電 機製ローターフレックス) で $\mathrm{Cu} K \alpha$ 線を用い $40 \mathrm{kV}$, $150 \mathrm{~mA}$ の条件で分析し, 焼結体の比表面積は, 窒素吸 着（Micromeritics 製 BET 装置 ASAP 2400）により求 めた。また，焼結体の硬度は，ビッカース硬度計（松沢 精機製 MV-1）で $1 \mathrm{~kg}$ の荷重で測定した。焼結体の破 壊鞁性は, IM 法でビッカースの圧子荷重 $5 \mathrm{~kg}$ を用い て測定した。曲げ強度は, JIS R 1601 の 3 点曲げ法（試 料寸法 $3 \times 4 \times 38 \mathrm{~mm}$, スパン長さ $30 \mathrm{~mm}$ ) に従い, 最 大引張り応力が発生する面が強化面になるよう試料を設 置し測定した。

\section{3. 結果及び考察}

\section{1 含浸溶液}

含浸後の熱分解工程を検討するためオキシ塩化ジルコ ニウムの加熱変化を調べた．オキシ塩化ジルコニウムの 熱分析結果によると, $100^{\circ} \mathrm{C}$ 付近でオキシ塩化ジルコニ ウムは, 水の蒸発に伴う急激な重量減少を示し, $150^{\circ}$ $400^{\circ} \mathrm{C}$ 付近にかけて結晶水の脱離とオキシ塩化ジルコニ ウムの分解による $\mathrm{ZrO}_{2}$ の生成に伴う緩やかな重量減少 を示した. したがってムライトの 1 次焼結体へオキシ塩 化ジルコニウムを含浸したあと, $\mathrm{ZrO}_{2}$ を生成させると きに 1 次焼結体に発生するクラックを防止するためには $400^{\circ} \mathrm{C}$ まで緩やかな熱分解工程が必要である。 また, 残 留 $\mathrm{Cl}^{-}$イオンによる焼結阻害 ${ }^{12)}$ を防止するため, 引き続 き $800^{\circ} \mathrm{C}$ 以上で残留 $\mathrm{Cl}^{-}$イオンを除去する必要がある.

\subsection{1 次焼成温度}

最適な表面強化層の厚みをもつムライト複合体を調製 


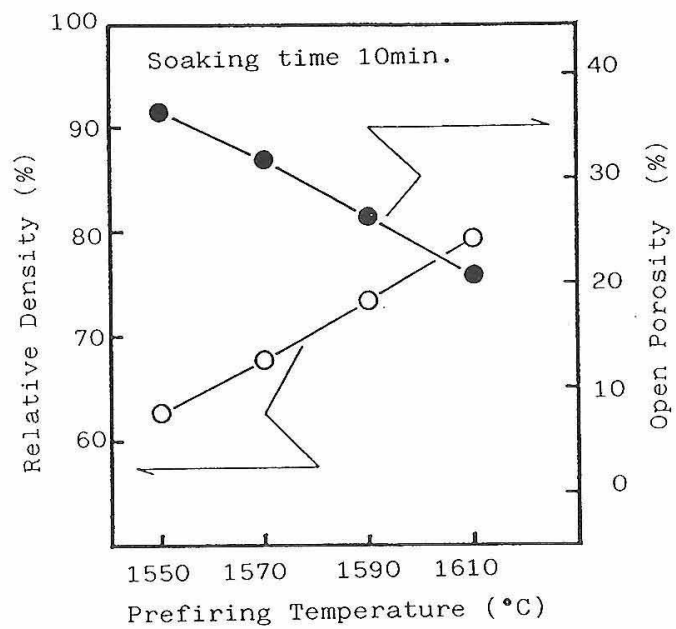

Fig. 1. Relation between the prefiring temperature and the relative density or the open prosity of the prefired mullite.

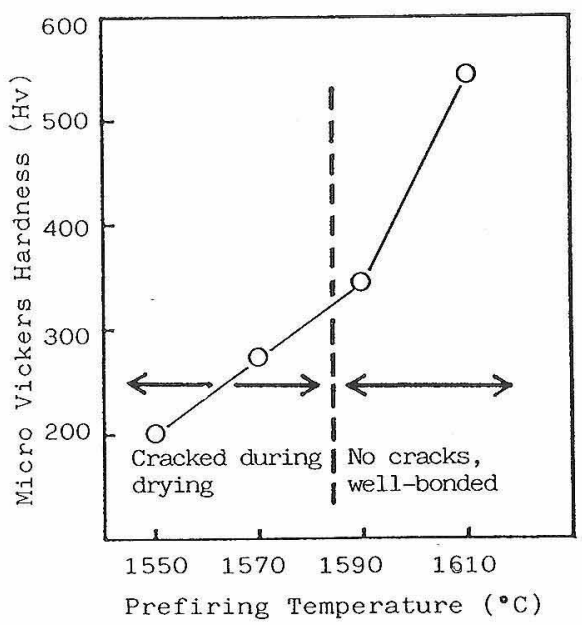

Fig.2. Relation between the prefiring temperature and Micro Vickers Hardness.

するために，まずはじめに 1 次焼結体の焼成温度と含浸 熱分解後のクラックの発生状況を調べた。図 1 に 1 次焼 成温度と相対密度及び開気孔の関係を示す。図 1 より 1 次焼成温度を $1550^{\circ} \sim 1610^{\circ} \mathrm{C}$ まで变化させることによ り，ムライト 1 次焼結体の開気孔を約 $20 \sim 40 \%$ の間で 自由に調節できることが分かった。これらの試料に，才 キシ塩化ジルコニウムを 8 分間含浸（含浸距離 $1 \mathrm{~mm}$ 前 後)させて含浸熱分解後のクラック発生状況を調べた。 含浸後の武料を, $5^{\circ} \mathrm{C} / \mathrm{min}$ 昇温速度で $400^{\circ} \mathrm{C}$ まで加 熱してオキシ塩化ジルコニウムを熱分解したところ， $1550^{\circ} \sim 1570^{\circ} \mathrm{C}$ で 1 次焼成した試料のみクラックが発生 した。しかし， $1590^{\circ} \sim 1610^{\circ} \mathrm{C}$ まで 1 次焼成温度を上げ た試料では，クラックの発生が防止できた。そこで，ク ラックの発生と 1 次焼結体の関係を明らかにするため,

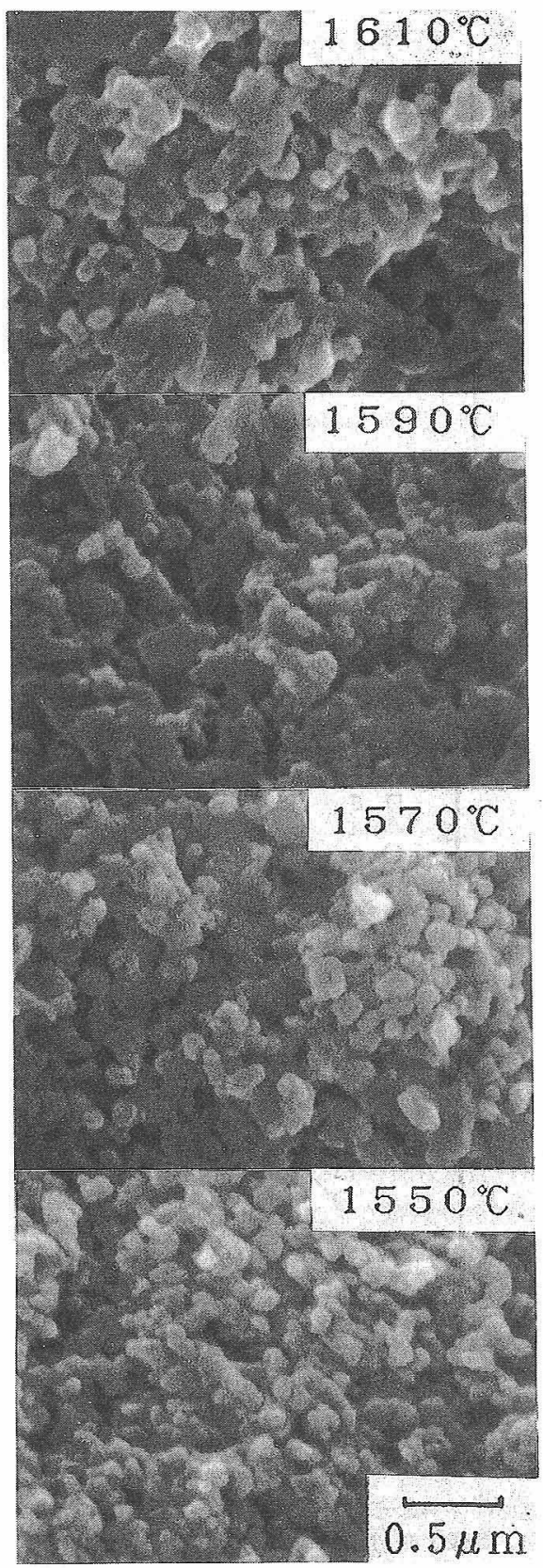

Fig. 3. SEM of the prefired mullite at $1550^{\circ}, 1570^{\circ}$, $1590^{\circ}$, and $1610^{\circ} \mathrm{C}$, for $10 \mathrm{~min}$.

1 次焼成温度と硬度の関係を調べた（図 2）ところ，よ い相関関係が得られた。すなわち，クラックの発生しな い安定した 1 次焼結体を得るには，本実験の場合，330 $\mathrm{Hv}$ 以上の硬度が必要となる。また図 3 に 1 次焼結体の SEM による微構造観察結果を示す１次焼成温度が低 すぎると，1 次焼結体中の粒子同士の結合が不十分で, 1 次焼結体内部の粒子の結合がそれほビ大きくなく，1 次焼成温度が高くなるにつれ，粒子同士の結合が強く 


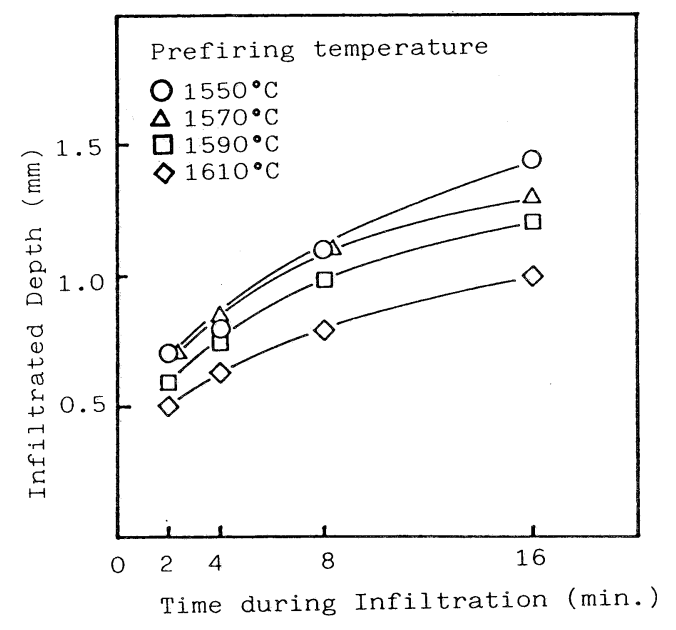

Fig. 4. Relation between the time during infiltration and the infiltrated depth on the each prefired mullite.

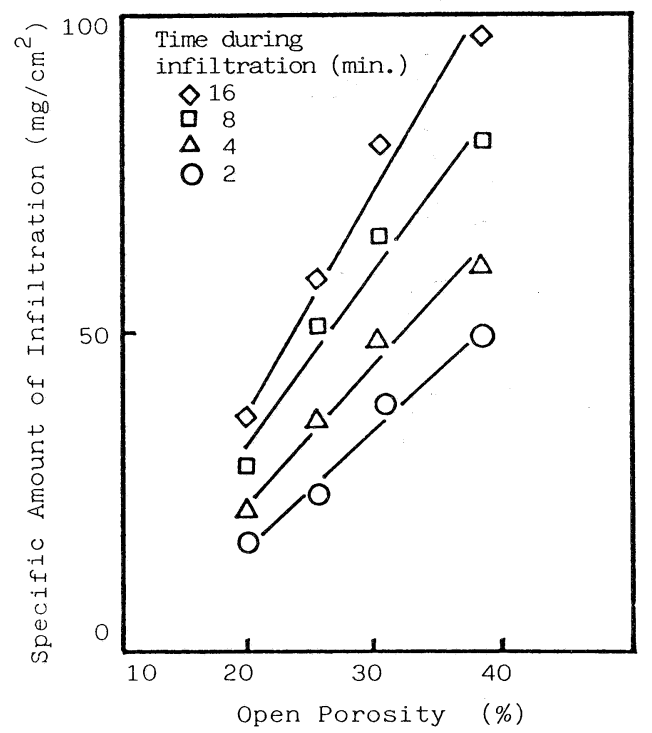

Fig.5. Relation between the specific amount of the infiltration and the open porosity of the each prefired mullite.

なっている様子が分かる。これらのことから，クラック の発生は，粒子同士の結合の度合いに依存するものと考 えられる。

\subsection{1 次焼結体と含浸距離及び含浸量の関係}

図 4 に，種々の 1 次焼成温度に対する含浸時間と含浸 距離の関係を示す。いずれの 1 次焼結体の含浸距離も, 含浸時間とともに増加し, やがて飽和する傾向を示した。 また，同一含浸時間における含浸距離を比較すると，1 次焼成温度の上昇とともに低下する傾向を示した。これ らの理由を調べるため，ムライト単位面積当たりの $\mathrm{ZrO}_{2}$ の含浸量すなわち比含浸量と開気孔率の関係を調 ベたところ, 比含浸量は, ムライト 1 次焼結体の開気孔

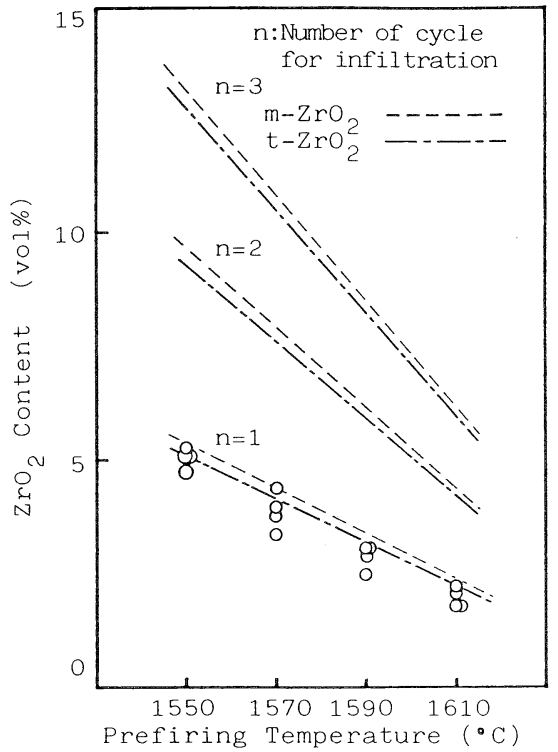

Fig. 6. Relation between the prefiring temperature and the $\mathrm{ZrO}_{2}$ contents in the modificated layers. The dash line indicates the $\mathrm{ZrO}_{2}$ contents calculated by the open porosity and the $\mathrm{ZrOCl}_{2}$ solution and the $(O)$ indicates the experimental the $\mathrm{ZrO}_{2}$ contents.

率之開気孔率 20４0％の範囲で比例関係を示すことが 明らかになった（図５）。これより，1 次焼結体中への 全含浸量は, 開気孔率と含浸溶液中の $\mathrm{ZrO}_{2}$ 濃度により 制御できるはずである. そこで, 1 回含浸について開気 孔率と含浸溶液中の $\mathrm{ZrO}_{2}$ 濃度加らもとめた含浸量（推 定值) と 1 回の含浸で得られる重量増加から求めた 2 次 焼結体中の $\mathrm{ZrO}_{2}$ の含浸量を比較した。図6より重量増 加から求めた実測值と推定值は良い一致を示し, 全含浸 量は, 開気孔率と含浸溶液中の $\mathrm{ZrO}_{2}$ 換算濃度により制 御できることが実証できた。

ところで, ムライトに $\mathrm{ZrO}_{2}$ を均一分散させた複合体 ${ }^{6 !}$ の結果によれば，ムライト $-\mathrm{ZrO}_{2}$ 複合体の機械特性を向 上させるには，10 vol％程度の $\mathrm{ZrO}_{2}$ を加える必要があ る。したがって， $\mathrm{ZrO}_{2}$ を表面部に含浸させる場合も表 面部に，少なくとも $10 \mathrm{vol} \%$ 程度の $\mathrm{ZrO}_{2}$ を加える必 要があると思われる. 今回作製した 1 次焼結体を用いる 場合, 1 次焼結体表面近傍部へ $\mathrm{ZrO}_{2}$ を $10 \mathrm{vol} \%$ 析出さ せるには, 1 次焼結体中の開気孔率は大きい方が良く, 本結果からは， $1590^{\circ} \mathrm{C}$ 焼結体（開気孔率 $26 \%$ ）が最適 である.しかし, 今回用いたオキシ塩化ジルコニウム溶 液による 1 回含浸での $\mathrm{ZrO}_{2}$ 析出量は，3 vol \% にすぎ ない. また, 含浸液中のオキシ塩化ジルコニウム濃度を 上げると溶液の粘性が高くなり，流動化がしにくくなる ため，ごく表面しか含浸ができなくなる，そこで，多段 含浸により析出量を増やす方法の検討を行った. 図 6 に 含浸回数に対する 2 次焼結体中の $\mathrm{ZrO}_{2}$ の含浸量の推定 


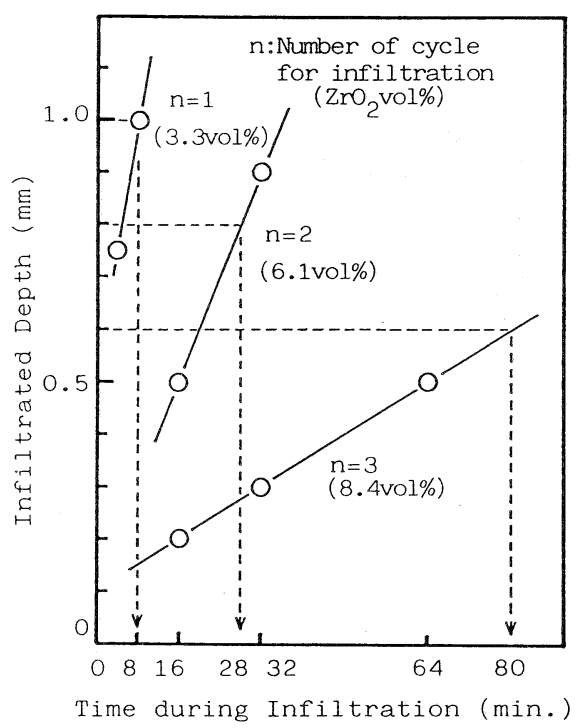

Fig. 7. Relation between the time during infiltration and the number of cycle for infiltration.

值を示した. 図中の 2 回目含浸の $\mathrm{ZrO}_{2}$ の含浸量（推定 値）は， 1 回含浸後の試料の熱分解により生成する $\mathrm{ZrO}_{2}$ 成分以外の部分が開気孔となると考え，残存する 開気孔とオキシ塩化ジルコニウム溶液中の $\mathrm{ZrO}_{2}$ 換算濃 度より計算した. 3 回含浸での含浸量の推定值も同様で ある. 図より, $1590^{\circ} \mathrm{C}$ で処理した 1 次焼結体に対し 2 次焼結体中の $\mathrm{ZrO}_{2}$ の複合量を $10 \mathrm{vol} \%$ 程度にするに は最低 3 回の含浸が必要である。ところで，複合体内部 のムライト単一層と表面含浸層との間で $\mathrm{ZrO}_{2}$ の急激な 組成変化があると, 2 次焼結体の製造時に表面層とバル ク層の界面でクラックの発生が予想できる。この問題を 解決するため, ムライト表面からムライト内部に向かっ て析出方向に $\mathrm{ZrO}_{2}$ の緩やかな濃度勾配を設けることに した。そこで， $1590^{\circ} \mathrm{C}$ で処理した 1 次焼結体に対し多 段含浸時における各含浸回数と含浸時間との関係を調べ た（図 7). 図中の 2 回含浸とは, 1 回含浸後の試料を加 熱しオキシ塩化ジルコニウムを熱分解させ表面層に $\mathrm{ZrO}_{2}$ を析出させたのち, オキシ塩化ジルコニウム溶液 を含浸させ熱分解により $\mathrm{ZrO}_{2}$ を再析出させたものであ る. 図中の実線は, 各含浸回数におけるオキシ塩化ジル コニウム（1 回含浸：3. $3 \mathrm{vol} \%, 2$ 回含浸 $: 6.1 \mathrm{vol} \%$, 3 回含浸 : $8.4 \mathrm{vol} \%)$ の到達深さを示している. 図 7 上 り, 含浸回数亡含浸時間とを組み合わせることにより含 浸距離に濃度勾配を設けることが可能である。すなわち， 含浸回数 1 回目, 2 回目, 3 回目に対してそれぞれ 8 分, 28 分, 80 分の含浸時間を設定するとムライト表面より $600 \mu \mathrm{m}$ までは, $\mathrm{ZrO}_{2}$ 濃度 $8.4 \mathrm{vol} \%, 600 \sim 800 \mu \mathrm{m}$ ま では 6.1 vol\%, 800〜1000 $\mu \mathrm{m}$ までは $3.3 \mathrm{vol} \%$ の順に 表面相の $\mathrm{ZrO}_{2}$ 濃度を変化させることができる。 そこで,

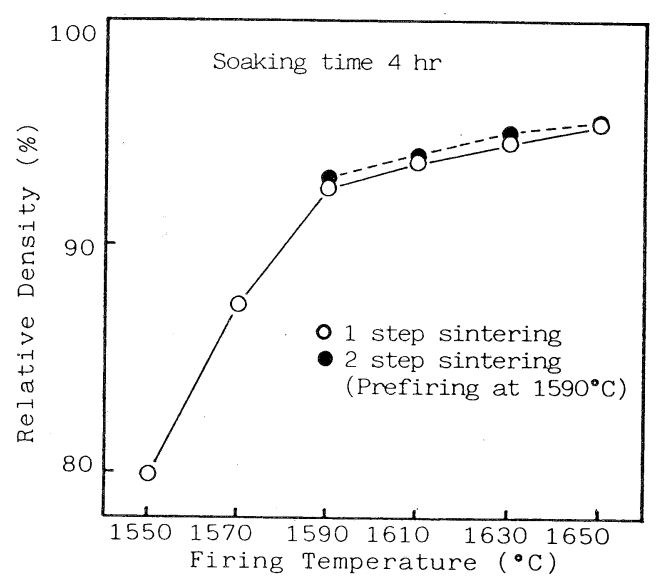

Fig. 8. Effect of firing conditions on the relative density.

以下に 3 回含浸の試料を作製し, 2 次焼成条件を検討し た。

\subsection{2 次焼成条件の検討}

今回用いた複合体の作製では, $\mathrm{ZrO}_{2}$ 含浸後の試料の 再焼成が必要之なるが，1 次焼成により，焼結性に大き な影響を与える比表面積の低下が認められた（成形体 $33.4 \mathrm{~m}^{2} / \mathrm{g}, 1590^{\circ} \mathrm{C}, 1$ 次焼結体 $\left.6.8 \mathrm{~m}^{2} / \mathrm{g}\right)$. これは, 焼 結体のち密化を引きおこす自由エネルギーの低下を意味 している.したがって，1 次焼結体を 2 次焼成しても得 られた焼結体がち密化しない可能性がある．そこで，焼 結体密度に及ぼす 2 段階焼成の影響について調べるため 直接 1 段階焼成で得られる焼結体との比較を行った。図 8 にその結果を示す. $1590^{\circ} \mathrm{C}$ で 1 次焼成した焼結体を 2 次焼成した焼結体の密度は，1段階で直接焼成した焼 結体の密度とほぼ同じであり焼結性の低下は認められな かった．以上の結果より，今回用いた 2 段焼結法では， 十分 2 次焼結体生成の自由エネルギーが残っていること が分かった。これは，1次焼結体の焼成時間を短く取っ たため, その過程での焼結エネルギーの減少はそれほど 大きくなく，2 次焼結体の生成工程でも焼結の駆動力は 十分に残っていたためだと考えられる。また，2次焼成 温度としては, 焼結体の相対密度が高い $1590^{\circ} \mathrm{C}$ 以上が 望ましい。

\section{5 複合体の微構造}

図 9 に $\mathrm{ZrO}_{2}$ を含浸したムライト複合体の表面から梁 さ方向に対して行った, $\mathrm{Zr}(L \alpha)$ の線分析結果之面分 析結果を示す. 図 9 (a) は, SEM と線分析結果を重补 たものであり, 図より $\mathrm{ZrO}_{2}$ 成分は, 3.3 節で設計した とおりムライト表面から約 $1 \mathrm{~mm}$ の深さまで浸透してお り，しかも表面から内側に向かい濃度勾配が認女られた。 また，図 9 (b) の面分析の結果から， $\mathrm{ZrO}_{2}$ 成分は表面 から深さ方向に対して同一平面上でも均一に分布してい 


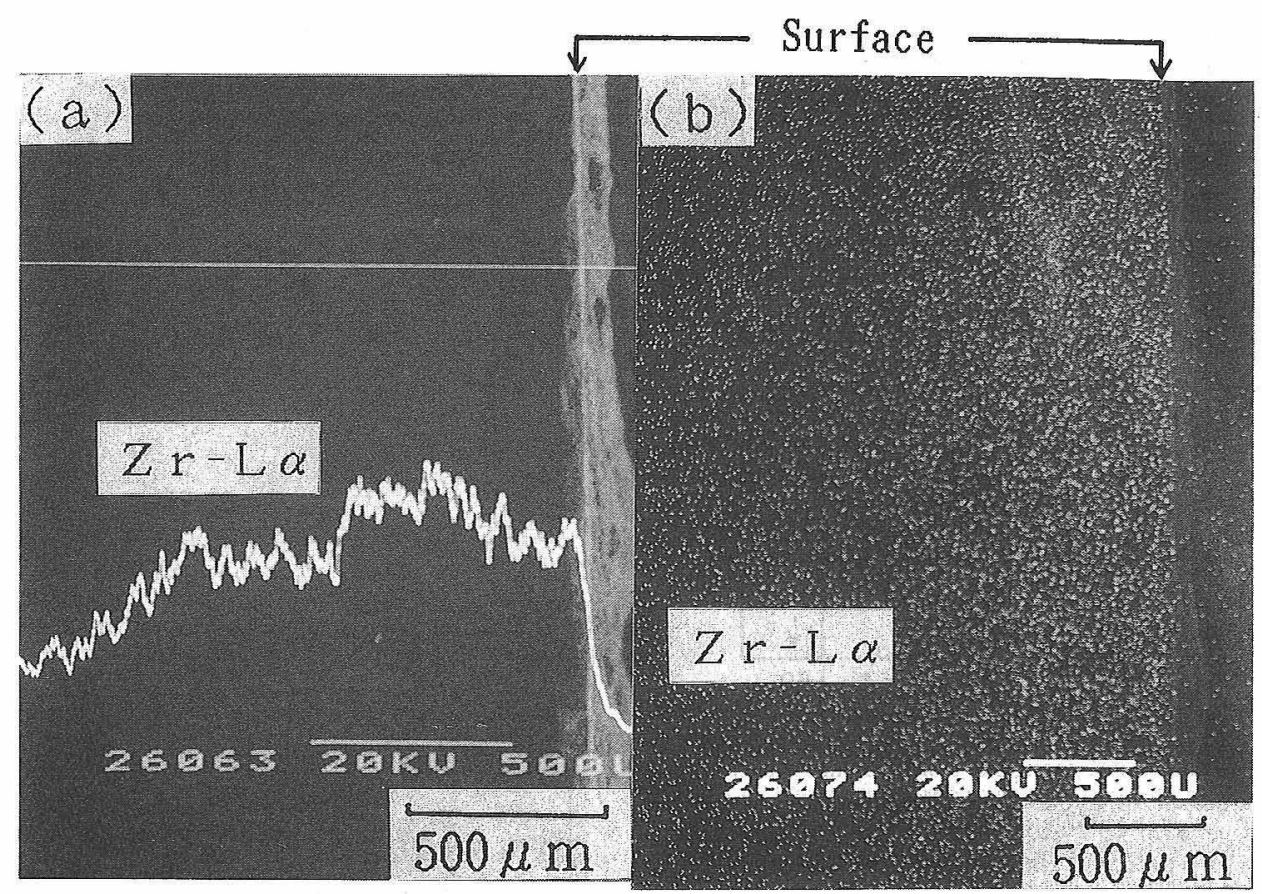

Fig. 9. $\mathrm{Zr}(L \alpha)$ line profile (a) containing its SEM image and the map (b) of the surface modified mullite by EPMA.

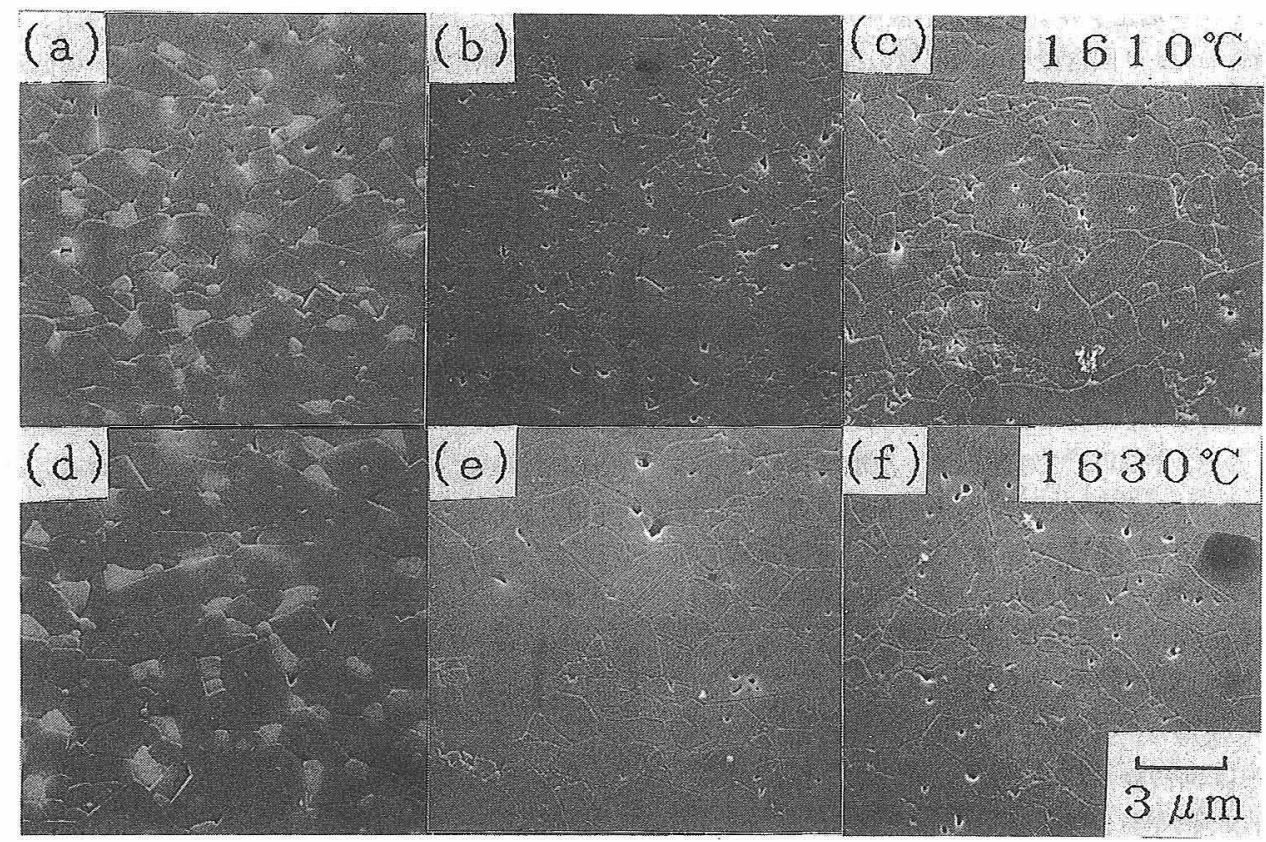

Fig. 10. SEM of structures of mullite (M) and surface modified mullite (M-Z) fired at $1610^{\circ}$ and $1630^{\circ} \mathrm{C}$ for $4 \mathrm{~h}$. (a), (d): the modified layer of $M-Z$ under $300 \mu \mathrm{m}$ from the surface,

(b), (e): the unmodified layer of $M-Z$,

(c), (f) : M

ることが確認できた。

2 次焼成温度 $1610^{\circ} \mathrm{C}$ と $1630^{\circ} \mathrm{C}$ につて, $\mathrm{ZrO}_{2}$ を含 浸したムライト複合体の微構造を SEM で観察した。図
10 に，2次焼成温度 $1610^{\circ} \mathrm{C}\left\llcorner 1630^{\circ} \mathrm{C}\right.$ につて，ムラ イト複合体表面加ら深さ方向に対して $300 \mu \mathrm{m}$ 入った表 面近傍部 ((a)，(d)) 及びムライト複合体の中心付近 
Table 1. Fracture toughness and flexural strength at room temperature and $1300^{\circ} \mathrm{C}$ of mullite and surface modified mullite fired at $1610^{\circ}$ and $1630^{\circ} \mathrm{C}$ for $4 \mathrm{~h}$

\begin{tabular}{|c|c|c|c|c|}
\hline \multirow[t]{2}{*}{ Sample } & \multirow{2}{*}{$\begin{array}{l}\text { Firing } \\
\text { Temp. } \\
\left({ }^{\circ} \mathrm{C}\right)\end{array}$} & \multicolumn{2}{|c|}{$\begin{aligned} \text { Flexural Strength } \\
$\[ (\mathrm{n}=3) \]$\end{aligned}$} & \multirow{2}{*}{$\begin{array}{c}\text { Fracture Toughness } \\
\text { of the surface } \\
\text { layer of composite } \\
\quad(\mathrm{n}=10) \\
\left(\mathrm{MPa} \cdot \mathrm{m}^{1 / 2}\right)\end{array}$} \\
\hline & & $\begin{array}{l}\text { Room Temp. } \\
\quad(\mathrm{MPa})\end{array}$ & $\begin{array}{r}1300^{\circ} \mathrm{C} \\
(\mathrm{MPa})\end{array}$ & \\
\hline M & 1610 & $377 \pm 34$ & $270 \pm 29$ & $1.62 \pm 0.09$ \\
\hline M & 1630 & $344 \pm 14$ & $301 \pm 47$ & $1.69 \pm 0.13$ \\
\hline$M-Z$ & 1610 & $518 \pm 12$ & $309 \pm 36$ & $3.45 \pm 0.06$ \\
\hline$M-Z$ & 1630 & $483 \pm 23$ & $298 \pm 39$ & $3.50 \pm 0.10$ \\
\hline
\end{tabular}

n : number of sample

((b), (e)) のSEM による微構造観察結果を示す。比 較のために，ムライト焼結体の SEM による微構造観察 ( (c), (f)) も併せて行った。図より，ムライト複合体 試料の表面近傍部では, $\mathrm{ZrO}_{2}$ の多くはムライトの粒界 付近に均一に分散し，ち密な複合体を形成していること が分かる. (a), (d) 面のX線回折より, ムライト中で の $\mathrm{ZrO}_{2}$ の存在形態は単斜晶之正方晶の両方であった. また, ムライト複合体の内部には, $\mathrm{ZrO}_{2}$ は存在せずム ライトだけが存在した.ムライト複合体内部の微構造は, SEM 観察からは，ムライト焼結体の微構造と同じであ る.ところで, ムライト焼結体のかさ密度は, $1610^{\circ} \mathrm{C}$ で $3.04 \mathrm{~g} / \mathrm{cm}^{3}, 1630^{\circ} \mathrm{C}$ で $3.09 \mathrm{~g} / \mathrm{cm}^{3}$ であり, ムライト 複合体のかさ密度は, $1610 \sim 1630^{\circ} \mathrm{C}$ の範囲で 3.17 $\mathrm{g} / \mathrm{cm}^{3}$ を示した. ムライト焼結体の相対密度を求めると 97〜98\%となった. 一方, $\mathrm{ZrO}_{2}$ を表面含浸したムライ 卜複合体のかさ密度を, 表面部に $\mathrm{ZrO}_{2}$ が均一にしかも, 傾斜濃度で入っているとして理論密度を計算し, それを 用いて相対密度を計算すると $99.0 \%$ となった.このこ とから，ムライト複合体は，十分ち密であることが裏付 けられた。ところで, 図 10 より, 焼結体の組織は, 2 次焼成温度の影響を受けやすく，焼成温度が高いほど粒 成長が起りやすいことが分かった。ムライトを焼結体で 使用する場合粒成長が進む之機械特性が低下するが，今 回得られたものには, $1630^{\circ} \mathrm{C}$ でも異常粒成長などは認 められず，良い焼結体微構造をしていた。

\section{6 曲げ強度と破壊鞋性}

3.5 節の調製法により作製したムライト複合体の機械 特性を測定した. 表 1 に, ムライト複合体の常温強度と 高温強度 $\left(1300^{\circ} \mathrm{C}\right)$ 及び破壊靶性值の結果を示す。比 較のために，ムライト焼結体の結果もあわせて示す。ム
ライト複合体の常温強度は，ムライト焼結体に比べて $35 \sim 40 \%$ 程度向上し，ムライト複合体の高温強度 $\left(1300^{\circ} \mathrm{C}\right)$ は, ムライトの高温強度並みの值を示した. これらの結果から, 今回作製したムライト複合体は, 常 温強度においてムライト焼結体よりすぐれ, 高温強度も ムライト並みと期待したとおりの性能を有することが分 かった. 更に, 今回得られたムライト複合体の表面層の 破壊勒性は，ムライト焼結体と比べて 2 倍以上となり, 破壊靶性が改善できた。

\section{4. 結 論}

ムライト表面に $\mathrm{ZrO}_{2}$ を均一に含浸する $\mathrm{ZrO}_{2}$ 表面強 化ムライト複合体の調製技術として，あらかじめムライ トを 1 次焼成して 20〜 40\%の開気孔率を持つ 1 次焼結 体を作製し, この焼結体に粘性の高いオキシ塩化ジルコ 二ウム溶液を含浸させ, 熱分解によりムライト表面近傍 にのみ $\mathrm{ZrO}_{2}$ を析出させたのち, 2 次焼成してち密で微 細な複合体を得る 2 段焼成法を確立した。

本法で得られた複合体の常温強度は，ムライトに比べ て 35 40\% 向上し, 高温強度もムライト並の值を維持 できた。更に，今回得られたムライト複合体の表面層の 破壊靶性は，ムライト焼結体と比べて 2 倍以上となり, 破壊靶性が改善できた。

\section{文献}

1) S. Kanzaki, H. Tabata, T. Kumazawa and S. Ohta, J. Am. Ceram. Soc., 68, C6-7 (1985).

2) P. C. Dokko, J.A. Pask and K. S. Mazdiyasni, J. Am. Ceram. Soc., 60, 150-55 (1977).

3) P.S. Lessing, R.S. Gordon and K. S. Mazdiyasni, J. Am. Ceram. Soc. , 58, 149 (1975).

4）神崎修三, 熊沢 猛, 浅海順治, 阿部修実, 田端英世, 窯協, 93，407-08 (1985).

5）山岸千丈, 上赤日出人, 浅海順治, “新素材シリーズ ム ライト2”，内田老鶴戋（1987）pp. 81-92.

6）窪田吉孝, 高木弘義, “新素材シリーズ ムライト $2 ”$, 内田老鶴圃 (1987) pp. 105-18.

7）芦塚正博, 奥野勉, 福田恵美子, 本田武史, 䇠田吉孝, 日本セラミックス協会年会講演予稿集, 1A13 (1989).

8）阿部 弘, 川合 実, 菅野隆志, 鈴木恵一朗, “エンジ二 アリングセラミックス”技報堂（1984）pp.167-71.

9) H. P. Kirchner and R. M. Gruvev, J. Am. Ceram. Soc., 49, 330-33 (1966).

10) S. J. Glass and D. J. Green, Adv. Ceram. Mater., 2, 129-31 (1987).

11) B. R. Marple and D. J. Green, J. Am. Ceram. Soc., 71, C471-73 (1988).

12) C.E. Scott and J.S. Reed, Am. Ceram.Soc. Bull., 58, 587-90 (1979). 